\title{
A produção dos significados sobre a homossexualidade em diferentes artefatos culturais
}

\begin{abstract}
Resumo: O presente artigo ${ }^{1}$ tem como objetivo investigar como alguns artefatos culturais - livros infantis, vídeos e revistas - vêm produzindo significados a respeito da homossexualidade. Para tanto, nossas análises estão alicerçadas no campo teórico dos Estudos Culturais, em suas vertentes pós-estruturalistas, que caracteriza os objetos analisados como resultados de um processo de construção social, ou seja, que os mesmos são constituídos por representações produzidas a partir de significados que circulam na cultura, sendo essa a justificativa que nos atrai a examiná-los. Nos artefatos culturais analisados, foi possível identificar que alguns livros infantis e vídeos através de suas narrativas ficcionais, visam desconstruir as representações acerca da homossexualidade, bem como promover o reconhecimento da pluralidade sexual e a promoção de uma cultura de respeito e de combate à homofobia. Entretanto, algumas revistas, em suas reportagens, vêm procurando explicar a origem e as possíveis causas da homossexualidade através do discurso das Ciências, de caráter reducionista e essencialista. Entendemos que esses artefatos mais do que falar sobre as experiências de vida, desejos, e - corpos desses sujeitos -, estão, ao mesmo tempo, produzindo e instituindo verdades sobre o que é ser homem, mulher, heterossexual, homossexual, entre outras identidades.
\end{abstract}

Palavras-chave: Homossexualidade. Gênero. Vídeos. Revistas. Livros infantis.

\section{Introdução}

Nos últimos anos, temos visto um debate crescente e intenso sobre homossexualidade e homofobia. Aliados a esse debate, também percebemos um aumento significativo no número de publicações a esse respeito, seja de dissertações e/ou teses, seja de artigos em periódicos, revista de divulgação, sites, livros, filmes, entre outros artefatos culturais. Esse incremento de publicações nos impulsionou a investigar como alguns artefatos culturais livros infantis, vídeos e revistas de divulgação - vêm produzindo significados a respeito da homossexualidade.

Nossas análises estão alicerçadas no campo teórico dos Estudos Culturais, em suas vertentes pós-estruturalistas, que caracteriza os objetos analisados como resultados de um processo de construção social. (SILVA, 2004) Nessa perspectiva, as revistas, programas de televisão, músicas, imagens, livros, filmes, jornais, dissertações/ teses, entre outros são considerados artefatos culturais, pois são constituídos por representações produzidas a partir de significados
(1) Pesquisa financiada pelo CNPq.

Paula Regina Costa Ribeiro Professora da Universidade Federal do Rio Grande - FURG. pribeiro@vetorial.net

Deise Azevedo Longaray Doutoranda do Programa de PósGraduação Educação em Ciências. Universidade Federal do Rio Grande - FURG.

deiselongaray@yahoo.com.br

Joanalira Corpes Magalhães Professora da Universidade Federal do Rio Grande - FURG.

Doutoranda do Programa de PósGraduação Educação em Ciências. joanaliracm@yahoo.com.br 
que circulam na cultura, sendo essa a justificativa que nos atrai a examiná-los. (FISCHER, 2002)

Os significados não são constantes e fixos, nem preexistentes, eles são fluidos, múltiplos, transitórios e incertos (HALL, 1997; SILVA, 2004), sendo produzidos por diversas instâncias sociais - família, mídia, escola, religião, hospital - e campos de saberes - biologia, psicologia, medicina, pedagogia, por exemplo - e circulam através de diferentes processos ou práticas culturais. Nessa perspectiva, os artefatos culturais nomeiam, classificam e definem a homossexualidade.

\section{Conhecendo os artefatos culturais}

Ao entendermos que a linguagem constitui os objetos de que fala, entendemos também que os significados e "os objetos" que dizemos existirem no mundo não existem a priori, mas são construídos nas práticas discursivas, vinculadas a regimes de verdade que lhes dão legitimidade. São essas construções, produzidas no interior de determinados discursos e práticas sociais imbricadas em relações de poder, que instituem os sujeitos e a cultura. Para Veiga-Neto (1996, p. 168), "[...] mais do que mediatizar, isso é, intermediar ou representar para nós o que é o mundo, a linguagem constrói o mundo [...] a linguagem constrói o que interessa do mundo, isso é, constrói os sentidos que damos ao mundo".

Por esse viés, percebemos o corpus de análise desta investigação como um conjunto de textos relacionados e conectados a diversas práticas culturais. Eles não são vistos como "realidades", as quais deveriam ser desveladas, com sentidos escondidos que seriam revelados por uma teoria definidora, que decifrasse o que se queria dizer com isso ou com aquilo, mas, sim, vê-los e percebê-los na sua materialidade, das coisas enunciadas em um determinado contexto temporal e espacial.

Nesse sentido, o que nos interessa ao "olharmos" esses artefatos é conhecer "o caráter móvel da linguagem e das representações" (MEYER; SOARES, 2005, p.36), problematizando os múltiplos significados produzidos sobre a homossexualidade. Para tanto, apresentamos como uma breve descrição do corpus de análise, tecendo algumas problematizações sobre como a homossexualidade, vem sendo narrada nessas produções culturais e como esses entendimentos vêm constituindo os sujeitos homossexuais. 


\section{Nas histórias infantis...}

O livro Olivia tem dois papais conta a história de uma menina muito esperta que tem dois pais, o Raul e o Luís. O livro traz a discussão da adoção por casais homossexuais: Olivia gostava que the contassem sobre sua história. Isso fazia com que se sentisse uma menina muito especial. - Por isso vocês me escolheram. E eu virei uma fitha e vocês viraram papai Raul e papai Luís! Os pais de Olívia gostam de brincar com ela de mamãe e filhinha ou com bonecas, o que possibilita problematizar sobre como a família atua na constituição das identidades de gênero ${ }^{2}$ através de práticas e discursos que instituem condutas, formas de falar, agir, brincar para cada sexo. Papai Raul, você também brincava de boneca quando era do meu tamanho? - Não filha eu brincava de outras coisas. Nem tinha boneca lá em casa. - Do que você brincava, então - Olivia insistiu. - De brincadeiras de menino, com o tio Roberto. Carrinho, futebol, videogame, luta, bicicleta. Coisas assim. -Então você nunca brincou de boneca?Nunca brincou de mamãe e filhinho? Que intrigante. [...] Se você nunca brincou de boneca ou de casinha, como foi que aprendeu a cuidar tão bem de uma fitha menina?- Ah, minha querida, tem coisas que a gente não precisa aprender, já nasce sabendo. Essa última fala embora problematize os atributos femininos, naturaliza o ser pai ou mãe ao dizer que "já nasce sabendo". Olívia também questiona os pais sobre coisas "indispensáveis" que as mulheres utilizam, tais como: maquiagem, sapato de salto alto e perfumes, pois ela gostava de se enfeitar e de ficar bonita. Essas situações narradas possibilitam discutir os atributos masculinos e femininos naturalizados na sociedade. A história também nos permite problematizar o preconceito em relação a sua família - O Lucas é muito bobo, papai, ele gosta de me provocar, dizendo que eu não tenho mãe. - Eu falo assim: "Eu não tenho mãe, mas tenho dois pais só para mim", o que também proporciona uma discussão sobre as "novas" configurações familiares.

O livro Meus dois pais inicia contando a história da separação dos pais de Naldo. Seu pai constituiu uma nova família com outro homem, mas o menino não sabia da identidade sexual ${ }^{3}$ de seu pai. A mãe de Naldo teve que ir para outra cidade devido a uma promoção no seu trabalho e não o levou junto. Assim, ele passou a morar com o pai e com seu companheiro, o Celso. A avó do menino não queria que ele morasse com o pai e fazia muitas perguntas quando ele ia a sua casa, a fim de saber se o garoto entendia a situação que
(2) De acordo com Louro (2007), as identidades de gênero são construçōes sociais e históricas, produzidas em relação às características biológicas, ou seja, os significados sociais atribuídos às masculinidades e às feminilidades são sempre produzidos no contexto de uma determinada cultura.

(3) Com relação às identidades sexuais, Louro (2007) afirma que essas construções se estabelecem e se codificam na sociedade, na história e na cultura e que dizem respeito às diferentes formas de expressar os prazeres e os desejos corporais. 
estava vivenciando - Você viu alguma coisa esquisita? - Vovó, por que você está falando desse jeito? O papai tem algum segredo? Qual é? Naldo acostumou-se com a vida nova e com o convívio com Celso que cozinhava muito bem e participava da sua educação. O livro traz à tona a questão do preconceito para com as relações homoafetivas, pois quando na escola os pais dos/as outros/as alunos/ as ficaram sabendo da situação, cochichavam - Comecei a perceber que falavam de mim na escola. Quando o Celso ou o papai iam me buscar, as mães de meus amigos ficavam cochichando. Um dia, cheguei a ouvir um pedaço da frase. - Pois é. Nem parece! Os pais não permitiam que os/as filhos/as fossem à casa do menino: - A minha mãe me proibiu de ir no seu apartamento - disse o Fê. [...] - É por causa do seu pai. [...] - O que o meu pai tem de errado? [...] - Seu pai é gay, Naldo! Depois da descoberta que seu pai era homossexual, Naldo ficou muito triste e revoltado e pediu para voltar para a casa da avó. Passado algum tempo, era seu aniversário e sua mãe retornara para a festa e conversara com Naldo sobre a situação, a fim de que o menino entendesse que existiam diferentes possibilidades de amor entre as pessoas. A mamãe falou bastante. Explicou que muitos homens e muitas mulheres são assim: amam seus iguais. E têm relacionamentos tão bonitos como os entre um homem e uma mulher, que são mais comuns. A mãe ainda complementa: Othe esses doces. Ambos são doces, mas diferentes entre si. Não é errado ser diferente! O menino também comenta situações de discriminações na escola contra os sujeitos que não se enquadram no "padrão" estabelecido pela sociedade. - Tinha um menino na minha classe. Chamavam ele de gayzinho. Mas o papai não é delicado, nem o Celso![...] - Tinha um bando de garotos que infernizavam a vida dele. Faziam piadas, xingavam. Até ameaçavam bater nele. Porém, Naldo passa a entender que o mais importante é ter uma família que se ama independente de todos os tabus presentes na nossa sociedade.

O livro O menino que brincava de ser conta a história de Dudu que brincava de ser bruxa, fada e princesa, na escola e na família. O artefato possibilita problematizar os marcadores identitários de meninos e meninas e seu entrelaçamento, além de proporcionar uma importante discussão sobre violência e patologização da homossexualidade. Foi Dudu quem inventou uma brincadeira na escola, brincar de ser. Essa brincadeira trouxe muitos problemas para o menino, a mãe dele ficou muito preocupada, pois ele nunca queria ser príncipe ou rei. Ela foi à escola, mas a professora dizia 
que não tinha problema algum. Teve um dia em que Dudu acordou com vontade de ser menina, sua mãe ficou extremamente preocupada sobre o que seu pai iria pensar, então resolveu levar o menino ao médico, o doutor Psicólogo, mas Dudu não entendia, o porquê desse procedimento, porque ele não estava doente. O psicólogo fez algumas perguntas sobre os personagens preferidos e Dudu respondeu: Gosto de um monte: quando eu vejo o desenho do Robin Hood, eu brinco de ser ele, quando eu vejo a Bela Adormecida, eu brinco de ser bruxa, eu gosto muito de ser bruxa... O psicólogo disse que não havia nada de errado com o menino, ele era muito inteligente e sensível. A mãe não se convenceu e levou o menino ao doutor Psiquiatra, depois ao doutor Endocrinologista e nenhum deles achou problema no Dudu. Um dia, ele resolveu se vestir com um vestido de sua mãe, o que causou um grande espanto: - Que negócio é esse? Você é mulherzinha? O pai não aguentava mais aquela situação e levou-o a uma escolinha de futebol para aprender a ser homem e também saiu para comprar brinquedos de homem: Dudu, vá colocar uma roupa decente que nós vamos sair, vou comprar uma bola para você. Você está precisando é de brinquedos de homem. Sua mãe fica comprando essas bobagens de fantasia, de joguinhos. Chega dessas coisas. Na escolinha de futebol o pai falou: - Se você não ficar quietinho e não fizer tudo o que o treinador mandar, vou the dar uma surra bem grande e colocá-lo de castigo! Seus avós paternos também não aceitavam as suas atitudes e colocavam a culpa na mãe: Menino homem quem tem que educar é o pai. Só quem entendia o Dudu era sua avó materna, inclusive lhe deu uma linda fantasia de bruxa, bordada com luas e morcegos. O menino sofria preconceito na escola, pois seus amiguinhos batiam nele e também o chamavam de mulherzinha. Um dia, sua avó materna resolveu levar Dudu ao teatro e ele viu os homens e as mulheres fantasiando-se, todos passavam batom, fato que o surpreendeu - Homem pode brincar de ser mulher e mulher pode brincar de ser homem, que ninguém liga? Ir ao teatro fez o menino repensar algo que não saía de sua cabeça, ele queria se transformar em menina, mas entendeu que podemos ser muitas coisas: - Vó, já sei! Eu quero ser um ator de teatro.

\section{Nos vídeos...}

O vídeo Pra quê time ele joga? busca discutir a homossexualidade a partir da história de um adolescente, chamado Pedro, que 
é um aluno muito bom em matemática e é o craque do time de futebol da escola em que estuda. Pedro nunca foi visto por seus/as colegas com uma garota, e por isso, a turma da escola "suspeitava da sua sexualidade. Em uma das cenas do vídeo, seus/as colegas presenciam o ex-namorado de Pedro roubando-lhe um beijo. Pedro, muito envergonhado, desiste de participar da partida final do campeonato de futebol da escola, bem como não sabe como reagir diante de todos esses fatos. E é nesse momento que Pedro recebe, em sua casa, a visita de seu professor de Educação Física e técnico do time de futebol, que assume para ele sua homossexualidade. O professor conversa com ele e comenta que ser diferente não é ser um anormal e, com isso, propiciando-nos uma discussão de que a homossexualidade não se constitui uma anormalidade. O professor incentiva Pedro a encarar a situação de frente, de maneira a lutar contra o preconceito, comentando que hoje é mais fácil aceitar a homossexualidade, os tempos são outros. Pedro, nesse momento, também recebe o apoio de seus pais e isso faz com ele se encoraje e decida voltar para escola, participando da partida final do campeonato. Em algumas cenas do vídeo, há um reforço acerca da masculinidade, é o que podemos evidenciar na fala de um dos colegas do time de futebol de Pedro, quando diz que eu nunca pensei que ia sentir tanta vontade de ter um gay ao meu lado naquela hora, mesmo sendo gay ele tinha que ser macho pra enfrentar aquela situação. Ao longo do vídeo, os/as alunos/as da escola de Pedro apresentam dúvidas e questões sobre a homossexualidade, que são respondidas e discutidas por uma orientadora educacional da escola. Dentre as questões levantadas pelos/as alunos/as, algumas apresentam a ideia de que gays são promíscuos e acabam morrendo de Aids. Além dessa, a orientadora discute que por um garoto ser sensível e demonstrar desinteresse por garotas, ele pode ou não ser gay, possibilitando desconstruir algumas representações acerca da homossexualidade, uma vez que se o menino foge ao esperado para o gênero masculino - atitudes, gestos, posturas, falas entre outras - é tido como gay.

O vídeo Medo de quê? é um desenho animado que foi produzido sem fala, a fim de ser apresentado em muitos países. Esse vídeo possibilita uma reflexão sobre as questões da homossexualidade e dos medos desses sujeitos frente a uma sociedade que os rejeita. Ele também nos proporciona refletir sobre a importância de uma sociedade mais plural, solidária e cidadã, no momento em que 
apresenta situações de violência homofóbica. O vídeo mostra a história de um garoto, Marcelo, que descobre sua atração-afetivo sexual por rapazes. No vídeo é mostrado como seus pais, seu melhor amigo e a comunidade em geral reagem frente às diversas situações vivenciadas pelo garoto. Além disso, são apresentadas cenas de aproximação de Marcelo com um garoto, inclusive a cena da primeira relação sexual dos mesmos, alertando para o uso do preservativo. Ao serem vistos juntos na rua, seus colegas debocham e, entre eles, está o seu melhor amigo, o João, que num primeiro momento, afasta-se de Marcelo e depois de pensar a respeito, retoma a amizade. Marcelo decide contar a seu pai que está atraído por um garoto. O pai ouve silenciosamente o que o filho tem a dizer, ao contrário da mãe que se mostra inconformada com a situação. No entanto, no final do vídeo, os pais de Marcelo são apresentados ao seu namorado e mostram aceitar a homossexualidade do filho.

No vídeo Boneca na mochila, um motorista de táxi conduz a mãe de um aluno até a escola. Ela foi chamada porque flagraram seu filho com uma boneca na mochila. Durante o trajeto percorrido até a escola, o motorista e a mãe do garoto ouvem um programa de rádio, em que a situação do garoto é discutida por especialistas. É interessante ressaltar que esses especialistas (psiquiatra, psicólogo, socióloga, orientadora sexual) tornam-se, nesse momento, as vozes "autorizadas" para falar da homossexualidade, o que acalma a mãe, que está desesperada com a situação. Ao longo da fala desses/as especialistas, emergem diversas explicações para que não se confunda o fato do menino estar com uma boneca na mochila com a homossexualidade - o que nos propicia problematizar o entrelaçamento das identidades sexuais com as de gênero. Entre as argumentações dos/as especialistas, podemos evidenciar as seguintes: A escola não está preparada para lidar com a diversidade, não discute a sexualidade na sala de aula no dia a dia, menino brincando com boneca está demonstrando sentimentos, os olhos de adulto veem aquilo que não existe, o menino está aprendendo a ser pai ao brincar de boneca, não é colocando um menino mais sensível no judô que ele vai deixar de ser homossexual e não é por isso que ele é ou será homossexual, não há promoção para a homossexualidade a partir de atividades (psicólogos); Escolas têm dificuldade em lidar com a criança sobre a questão da sexualidade, hoje há mais liberdade e oportunidade de se expressar, comportamentos são de conotação diferente na infância (orientadora sexual); entre outras questões. Em um dado momen- 
to, a mãe atribui a culpa da situação ao pai do garoto que é muito ausente. Isso propicia a discussão de que a ausência do pai, que é tido como referência de masculinidade, pode influenciar a homossexualidade. No decorrer do filme, o taxista também (re)pensa sua postura, uma vez que no início de toda a discussão ele dizia que se sua filha fosse homossexual, a surraria para ela aprender. O vídeo termina com a cena da mãe chegando à escola.

\section{Nas revistas de divulgação científica...}

A revista Veja, a partir da matéria intitulada A diferença se vê no cérebro - descoberto que os homossexuais são mais parecidos com pessoas do sexo oposto, (VIEIRA, 2008) discute a "natureza" da homossexualidade, questionando se ela seria determinada por fatores biológicos ou culturais, e mobilizando, dessa forma, a psicologia e outros campos da ciência a tal questionamento. A revista coloca:

Até meados do século XX [...] o homossexualismo era catalogado pela Organização Mundial de Saúde como distúrbio mental e a culpa quase sempre recaía sobre a educação recebida dos pais. Freud considerava a homossexualidade uma forma de retardo no desenvolvimento do indivíduo, causado por um pai ausente ou por uma mãe superprotetora..

Nessa direção, é colocado que os estudos mais recentes vêm apontando que muito além das experiências de vida, o indivíduo torna-se homossexual por fatores biológicos. Em seguida, comenta sobre a pesquisa realizada pelo Stockolm Brain Institute, do Instituto Karolinska, na Suécia, comentando que essa foi

[...] recebida pelo meio científico como a prova mais consistente até hoje do peso do fator biológico na homossexualidade. A conclusão da pesquisa mostra que o cérebro de pessoas homossexuais se assemelha mais ao de indivíduos do sexo oposto do que ao de heterossexuais do mesmo sexo.

A reportagem aponta que noventa voluntários foram submetidos a exames de tomografia e ressonância magnética no cérebro e que os resultados encontrados pelos cientistas foram: tanto homens heterossexuais quanto mulheres homossexuais apresentam o hemisfério cerebral direito um pouco maior que o esquerdo. 
Entre homens homossexuais e mulheres heterossexuais, volume dos dois hemisférios é equivalente.

A revista Época, na matéria intitulada Qual é o sexo do seu cérebro?, (FERREIRA, 2009) aponta que as diferenças no corpo de homens e mulheres estão além da aparência e dos órgãos sexuais e que a ciência detectou que até o cérebro apresenta características femininas ou masculinas. Na reportagem é colocado:

Você consegue saber se seu amigo está triste ou irritado só de olhar para ele? Essa é uma característica de um cérebro feminino. Mas um homem também pode ter essa sensibilidade e outros comportamentos geralmente ligados a um cérebro feminino. Isso porque a sexualidade cerebral não está ligada diretamente ao sexo do corpo. [...], diz a ÉPOCA a neuropsicologista Anne Moir, da Universidade de Oxford, na Inglaterra.

Ao longo da matéria, a pesquisadora Moir acredita que a "diferença de sexo" entre cérebro e corpo está ligada às causas da homossexualidade, a mesma destaca: "Se a concentração de testosterona no útero está mais baixa do que o padrão para os homens, então o 'centro sexual' do cérebro será feminino e esse homem sentirá atração por outros homens". Ainda é mencionado que para entender melhor essas diferenças neurológicas, a pesquisadora está desenvolvendo um teste que mostra - numa escala de 1 a 20 - qual é o sexo do cérebro, sendo que o número 1 representa o cérebro mais masculino possível, 20 o mais feminino e quem se aproxima do 10 tem um cérebro misto. Além disso, ainda era mencionado na revista que "[...] geralmente, quem tem cérebro masculino tem o dedo indicador menor que o anelar (olhando para a mão de frente para a palma). Já cérebros femininos são associados a dedos indicadores do mesmo comprimento que os anelares". O teste é composto por 20 perguntas e tem como opções de resposta não ou sim. As perguntas contemplavam questões relacionadas ao ato de cantar afinado, competição, capacidade de escuta, subir em árvore, execução de tarefas, categorizar objetos, preferências de livros, sensibilidade, orientação espacial, entre outros aspectos.

A revista Galileu apresenta a matéria intitulada O polêmico gene gay - A relação entre genética e homossexualidade vive sendo provada e contestada. Agora, o maior estudo sobre o assunto quer responder: é possivel nascer homossexual? (NOGUEIRA, 2007) discute que há quase duas décadas, psicólogos, geneticistas e neurologistas vêm 
coletando amostras das diferenças biológicas entre heterossexuais e homossexuais, as quais perpassam a "[...] influência da genética (o irmão gêmeo de um gay tem mais chance de ser também), habilidades manuais (gays de ambos os sexos têm mais chances de serem canhotos) e cognitivas (lésbicas têm um raciocínio de rotação espacial melhor do que as heteros)". Ao longo da reportagem, é realizada uma compilação das principais pesquisas realizadas sobre a questão da homossexualidade e sua origem biológica. Ao final da reportagem, são apresentados quadros contendo os resultados dos principais estudos relacionados à homossexualidade. A primeira categoria de estudos apresentada pela revista mostra aqueles que envolvem famílias e gestação, os quais, de acordo com a reportagem, respondem por grande parte dos argumentos que sustentam a ideia de uma base biológica para a homossexualidade, mostrando os principais resultados. São eles: "mães de gays são mais férteis - Seja por causas biológicas ou sociais, o fato é que gays possuem mais irmãos do que a população em geral"; "homossexualidade entre irmãos - Um homem com um irmão gay tem mais chances de ser também gay. o efeito é maior no caso de gêmeos idênticos"; "estruturas cerebrais - Em 1991, um estudo detectou diferenças de tamanho numa estrutura do hipotálamo conhecida como INAH3. em 2001, outra pesquisa, avaliando a mesma região cerebral, encontrou maior quantidade de neurônios nos cérebros dos homossexuais"; "influência hormonal - Vários estudos mostram que filhos de mulheres nascidas com hiperplasia adrenal congênita [...] tendem a apresentar maior interesse por relações homossexuais quando adultos". A outra categoria intitulava-se diferenças aparentes, que destacava: "Pesquisas que apontam diferenças físicas e psicológicas entre gays e heterossexuais são ainda mais polêmicas". Os resultados mostrados estavam relacionados à análise do couro cabeludo - "Homossexuais apresentam duas vezes mais redemoinhos no sentido anti-horário" -, da preferência da mão "Gays e lésbicas têm muito mais chances de serem canhotos que a população em geral" -, da relação entre os dedos - "o tamanho dos dedos anelar e indicador é mais próxima entre as lésbicas do que entre as heterossexuais" -, do tom de voz - "Homens e mulheres ouviam vozes de pessoas e tinham de adivinhar sua orientação sexual. $62 \%$ acertavam quando um gay falava" - e do pensamento espacial - "A habilidade com problemas tridimensionais varia de acordo com a opção sexual". 


\section{E assim, os significados vão sendo produzidos...}

Nos artefatos culturais analisado, foi possível identificar que os livros infantis e os vídeos através de suas narrativas ficcionais ${ }^{4}$ visam desconstruir as representações acerca da homossexualidade, bem como promover o reconhecimento da pluralidade sexual e a promoção de uma cultura de respeito ao grupo LGBT (lésbicas, gays, bissexuais, transgêneros - travestis e transexuais). Esses artefatos, através de seus/as personagens, buscam ampliar as discussões através de uma linguagem para crianças e adolescentes a fim de desconstruir conceitos hegemônicos, tais como: a heterossexualidade como norma, a família branca, nuclear, de classe média e ocidental, os atributos socialmente estabelecidos para homens e mulheres, entre outros.

As revistas, em suas reportagens, vêm tentando explicar a origem e as possíveis causas da homossexualidade através do discurso das Ciências. O que observamos é que a Ciência, a partir das pesquisas apresentadas nesses artefatos, atua como um dispositivo de controle através de uma série de diagnósticos, padrões a serem seguidos e estratégias que buscam comprovar que esses sujeitos se desviam da norma. Para isso, a Ciência se vale do progresso da razão, produzindo conhecimentos que se tornam válidos, entrando na ordem discursiva e engendrando o funcionamento de uma sociedade normalizada, determinando o saber verdadeiro e o falso a partir de critérios científicos modernos.

Foi possível evidenciar que alguns desses artefatos possibilitam problematizar a homossexualidade como doença, uma vez que muitos/as ainda a veem dessa forma. Considerando que a homossexualidade é uma entre as possíveis identidades sexuais, mas que socialmente a identidade entendida como "normal" é a identidade a heterossexual, torna-se importante discutir a construção histórica e social da mesma, de forma a não reforçar os estigmas atribuídos a essa identidade, que resulta, muitas vezes, em preconceito e discriminação aos/às homossexuais.

A homossexualidade recebe seu caráter de "anormalidade", uma vez que transcende e não obedece, muitas vezes, ao padrão imposto socialmente ao gênero masculino ou feminino. Desse modo, "[...] a homossexualidade se mostra como locus de transgressão e de recriação da dicotomia homem/mulher" (MONTEIRO, 199-), ou seja, do comportamento considerado "apropriado" aos homens e às mulheres, o que possibilita uma discussão sobre o entrelaçamento

(4) "É a narrativa ficcional, em sua criação da realidade, através da ação de personagens imaginários numa trama também imaginária que torna possivel a catharsis: o emocionar-se frente à obra impactar-se por ela, recriá-la". (MATTOS, 199-) 
(5)Operamos com o termo homofobia, no sentido de manifestação de ódio, repulsa, aversão, nojo, etc. não somente em relacão aos/às homossexuais, mas também a transgêneros (travestis e transexuais) e bissexuais. Borrillo (2009, p. 18) destaca que a “[...] homofobia é um fenômeno complexo e variado. Podemos entrevê-la em piadas vulgares que ridicularizam o indivíduo efeminado; no entanto, ela pode revestir-se também de formas mais brutais." das identidades de gênero às identidades sexuais. Nesse sentido, alguns dos artefatos analisados buscam desconstruir as representações de homens e mulheres, pois questionam os diversos atributos de gênero que são produzidos pela nossa sociedade. Contudo, ainda percebemos que aqueles/as que não correspondem às atribuições feitas para determinado gênero passam a ser discriminados/as, ou seja, "[...] aqueles/as que transgridem as fronteiras de gênero e sexualidade, que atravessam ou que, de algum modo, embaralham e confundem os sinais considerados 'próprios' de cada um desses territórios são marcados como sujeitos diferentes e desviantes". (LOURO, 2004, p. 87)

Além disso, alguns desses artefatos possibilitam a discussão da temática homofobia ${ }^{5}$, uma vez que evidenciam, em suas narrativas, situações de exclusão social. Esses artefatos também apresentam e nos permitem discutir as "novas" configurações familiares presentes em nossa sociedade, ou seja, a de famílias homoafetivas, formadas por dois pais ou duas mães possibilitando-nos, assim, problematizar a homofobia nesse contexto.

Desse modo, é possível entender que as representações sobre a sexualidade constroem relações de distinção social, que incidem na fabricação de sujeitos homossexuais e heterossexuais, ou seja, vamos aprendendo, desde muito cedo, a ocupar e reconhecer os lugares sociais através de um complexo de forças e de processos que incluem instâncias como os meios de comunicação de massa, a ciência, as revistas, os brinquedos, a literatura, o cinema, a música e que produzem, por exemplo, diferentes e conflitantes formas de conceber e de viver nossas identidades sexuais e identidades de gêneros. Entendemos que esses artefatos mais do que falar sobre as experiências de vida, desejos e corpos desses sujeitos estão, ao mesmo tempo, produzindo e instituindo verdades sobre o que é ser homem, mulher, heterossexual, homossexual, entre outras identidades.

Assim, conforme Foucault (2007), a homossexualidade não é simplesmente uma identidade sexual e ocupação do corpo, mas é, sobretudo, discurso, investigação, conhecimento, criação de significados, troca simbólica, enfim, herdeira legítima da vontade de saber. 


\title{
The production of meanings on homosexuality in different cultural artifacts
}

\begin{abstract}
This article aims to investigate how some cultural artifacts children's books, videos and magazines - have been producing meanings on homosexuality. For so, our analysis is grounded in the theoretical field of Cultural Studies, in its poststructuralist strands, which characterizes the analyzed objects as the result of a social construction process: they consist of representations produced from meanings spread in the culture, being the reason that attracts us to examine them. From the analyzed cultural artifacts, we found that children's books and videos, through their fictional narratives, seek to deconstruct the representations of homosexuality as well as promote the recognition of sexual diversity and a culture of respecting and combating homophobia. Magazines, in the other hand, when reporting, have been seeking to explain the origin and possible causes of homosexuality through the discourse of Science, in its reductionist and essentialist character. More than talking about life experiences, desires, the bodies of these subjects, we understand that these artifacts are at the same time producing and establishing truths about what is to be male, female, heterosexual, homosexual, among other identities.
\end{abstract}

Keywords: Homosexuality. Gender. Vídeos. Magazines. Infant books.

\section{Referências}

BONECA na mochila. Produzido pela ECOS - Comunicação, 25 min, Brasil. [2011] Filme/DVD

BORRILlO, Daniel. A homofobia. In: LIONÇO, Tatiana; Diniz, Debora. Homofobia e educação: um desafio ao silêncio. Brasília, DF: Letras Livres: Ed. UnB, 2009. p. 15-46.

CARRASCO, Walcyr. Meus dois pais. São Paulo: Ática, 2010. 40p.

FERREIRA, Taís. Qual é o sexo do seu cérebro? Época, Rio de Janeiro, 25 mar. 2009. Disponível em: < http://revistaepoca.globo.com > . Acesso em: 22 jan. 2011.

FISCHER, Rosa M. Bueno. O dispositivo pedagógico da mídia: modos de educar na (e pela) TV. Educação e Pesquisa, São Paulo, n.1, p. 151-162, jan./jun. 2002.

FOUCAULT, M. História da sexualidade I: a vontade de saber. 18. ed. Rio de Janeiro: Graal, 2007.

HALL, Stuart. The work of representation. In: (Ed.) Representation: cultural representations and signifying practices. London: Thousand Oaks, Calif.: Sage in association with the Open University, 1997.

LEITE, Márcia. Olivia tem dois papais. São Paulo: Companhia das Letrinhas, 2010. 46 p.

LOURO, Guacira Lopes. Um corpo estranho: ensaios sobre sexualidade e teoria queer. Belo Horizonte: Autêntica. 2004.

LOURO, Guacira Lopes. Pedagogias da sexualidade. In: et al 
(Org.). O corpo educado. Belo Horizonte: Autêntica. 2007.

MARTINS, Georgina da Costa. O menino que brincava de ser. 3. ed. São Paulo: DCL, 2008. 78p.

MATTOS, Paulo André Passos de. Entre as narrativas literária, filmica e historiográfica: artes do tempo na produção dos saberes históricos. [199-] Disponível em: http://www.ufmt.br/revista/arquivo/rev14/entre_as_ narrativas_literaria.html. Acesso em: 5 jun. 2011.

MEDO de quê?. Direção Reginaldo Bianco, 2005, 18min, Brasil. Filme/ Animação/DVD

MEYER, Dagmar Elisabeth Estermann; SOARES, Rosângela de Fátima. Modos de ver e de se movimentar pelos "caminhos" da pesquisa pós-estruturalista em educação: o que podemos aprender com - e a partir de - um filme. In: COSTA, Marisa Vorraber (Org.). Caminhos investigativos III: riscos e possibilidades de pesquisar nas fronteiras. Rio de Janeiro: DPEA, 2005. p. 23-44.

MONTEIRO, Marko. O pós-estruturalismo no estudo do gênero. [199-] Disponível em: < http://www.artnet.com.br/ marko/laymert.html >. Acesso em: 10 jun. 2011.

NOGUEIRA, Pablo. O polêmico gene gay: a relação entre genética e homossexualidade vive sendo provada e contestada: agora, o maior estudo sobre o assunto quer responder: é possível nascer homossexual?. Galileu, n. 1978, dez. 2007. Disponível em: www.revistagalileu.globo.com. Acesso em: 22 jan. 2011.

PRA quê time ele joga?. [2009] Produzido por 3 laranjas comunicação, 25 min, Brasil. Filme/DVD

SILVA, Tomas Tadeu da. Documentos de identidade: uma introdução às teorias do currículo. Belo Horizonte: Autêntica, 2004.

VEIGA-NETO, Alfredo. A didática e as experiências de sala de aula: uma visão pós-estruturalista. Educação e Realidade, v. 21, n. 2, p. 161176, jul.-dez. 1996.

VIEIRA, Vanessa. A diferença se vê no cérebro: descoberto que os homossexuais são mais parecidos com pessoas do sexo oposto. Veja, 20 jun. 2008. Disponível em: <www.veja.abril.com.br >. Acesso em: 22 jan. 2011.

Artigo submetido em 30/06/2011 e aceito para publicação em 3/10/2011 